\title{
Differential Regulation of Natriuretic Peptide Receptor Messenger RNAs during the Development of Cardiac Hypertrophy in the Rat
}

Lesley A. Brown, Derek J. R. Nunez, and Martin R. Wilkins

Department of Clinical Pharmacology, The Royal Postgraduate Medical School, Hammersmith Hospital, London W12 0NN, United Kingdom

\begin{abstract}
The heart expresses the three natriuretic peptide receptors (NPR), namely NPR-A, NPR-B, and NPR-C. We have examined the temporal relationship between the expression of mRNA transcripts for atrial natriuretic peptide (ANP) and brain natriuretic peptide (BNP) and their receptors in the heart during the development of cardiac hypertrophy in the aortovenocaval fistula rat. Messenger RNAs were measured by cDNA amplification. Progressive cardiac hypertrophy was accompanied by increased ANP mRNA prevalence throughout the heart and increased BNP mRNA in the left atrium. The most striking observation was the gradual disappearance of NPR-C transcripts (the putative "clearance" receptor) in all chambers; this was in marked contrast to the increase in mRNA levels for NPR-A and NPR-B (the guanylyl cyclase-linked receptors). Our observations have important therapeutic implications if the transcript changes are mirrored at the receptor protein level because $(a)$ the apparent down-regulation of NPR-C may enhance the local action of natriuretic peptides on the heart, and (b) the loss of NPR-C, particularly if it is widespread, may reduce the rate of elimination of the natriuretic peptides, restricting the therapeutic potential of specific NPR-C ligands designed to reduce peptide clearance. (J. Clin. Invest. 1993. 92:2702-2712.) Key words: arteriovenous shunt $\bullet$ atrial natriuretic peptide $\bullet$ brain natriuretic peptide $\bullet$ clearance $\bullet$ guanylyl cyclase $\cdot$ heart
\end{abstract}

\section{Introduction}

Atrial natriuretic peptide (ANP), ${ }^{1}$ brain natriuretic peptide (BNP), and C-type natriuretic peptide (CNP) constitute a family of peptides sharing sequence, structural, and functional similarities (1-3). They are encoded by different genes and the

\footnotetext{
Address reprint requests to Dr. Martin R. Wilkins, Department of Clinical Pharmacology, The Royal Postgraduate Medical School, Hammersmith Hospital, Du Cane Road, London W12 0NN, United Kingdom. 1993.

Received for publication 20 May 1993 and in revised form 19 July

1. Abbreviations used in this paper: ANP, atrial natriuretic peptide; AV, aortovenocaval; BNP, brain natriuretic peptide; CNP, C-type natriuretic peptide; CV, coefficient of variation; G3PDH, glyceraldehyde3-phosphate dehydrogenase; LA and RA, left and right atria; respectively; LV and RV, left and right ventricles, respectively; NPR, natriuretic peptide receptor; $\mathrm{RT}$, reverse transcription.
}

J. Clin. Invest.

(C) The American Society for Clinical Investigation, Inc.

$0021-9738 / 93 / 12 / 2702 / 11 \quad \$ 2.00$

Volume 92, December 1993, 2702-2712 biologically active species are cleaved from the carboxyl termini of their respective precursor molecules (4-6). ANP and BNP are present in many tissues, the highest levels occurring in atrial myocytes $(1,7)$. CNP, in contrast, is located primarily in the brain and pituitary gland, with very low levels in other tissues (8). Recently, CNP has been detected in endothelial cells in culture $(9,10)$ and in endothelium in situ (11).

Collectively, the natriuretic peptide family is thought to play an important role in cardiovascular homeostasis. ANP and BNP exhibit natriuretic-diuretic and vasorelaxant properties through a direct action on tissues and by "antagonism" of the renin-angiotensin system, endothelin, and vasopressin (1, 12). CNP, in contrast to the other natriuretic peptides, is predominantly a vasodilator and has little effect on, or reduces, renal sodium and water excretion $(3,13,14)$. The effects of these peptides appear to be mediated by guanosine 3 ',5'-cyclic monophosphate (cGMP) (1), although there are indications that they may alter intracellular cAMP $(1,15-20)$ and phosphoinositide concentrations (21-23). ANP and CNP also have an antiproliferative action on vascular smooth muscle cells in culture $(24,25)$; these antimitogenic effects have been reported to occur independently of changes in cellular cyclic nucleotide levels (24).

To date, cDNA cloning has defined three types of receptor for the natriuretic peptides (NPR-A, -B, and -C) (26-33). Expression of NPR-A and NPR-B cDNAs demonstrate that both possess an integral intracellular guanylyl cyclase domain (26$30,34)$. However, the two receptors display different ligand binding selectivity. The rank order of binding to NPR-A and potency at generating cGMP is ANP $>\mathrm{BNP} \gg \mathrm{CNP}$, whereas for NPR-B it is CNP $\gg$ ANP $\geq$ BNP (34-37). The third receptor, NPR-C, has a short intracellular tail (31-33) and no intrinsic ability to generate cGMP, although it may mediate the changes in cAMP (17-22, 38, 39) and phosphoinositides (23) mentioned above. It has less stringent requirements for ligand binding than the other two forms-it binds the three natriuretic peptides with approximately equal affinity, as well as ring-deleted and truncated linear peptides $(36,37,40)$. Binding to NPR-C appears to be an important route of elimination of the natriuretic peptides $(41,42)$.

ANP and BNP have been studied primarily as circulating hormones, but there is increasing interest in potential paracrine and autocrine actions of these peptides in various tissues, including the heart. The presence of functional receptors in the heart has been suggested by several studies of the effects of natriuretic peptides on isolated myocardium or myocytes (4346). Specific cardiac binding sites for these peptides have been detected by ligand binding studies or autoradiography (47, 48 ), but not consistently (49; D. J. Nunez, unpublished observations), possibly because of high local concentrations of endogenous ANP released during the sample preparation. However, the presence of receptor mRNA transcripts has now been demonstrated clearly in the monkey heart using in situ hybrid- 
ization (50) and in rodent and human cardiac tissue by cDNA amplification with the reverse-transcription polymerase chain reaction (RT-PCR) (51).

The factors influencing the expression of the NPR in cardiac tissue are central to an understanding of the role of these peptides in regulating cardiac function. A recent study suggested that the expression of mRNA transcripts for the receptors in the human heart may be modified by pressure or volume overload (51). In the present study, we have examined the temporal relationship between the expression of ANP and BNP, their receptors and increasing cardiac mass in a rat model of progressive four chamber cardiac hypertrophy and elevated plasma ANP levels, the aortovenocaval (AV) fistula rat (52, 53). This has been accomplished using RT-PCR, as the technique provides a rapid approach to quantifying the expression of multiple genes in the same small cDNA sample.

\section{Methods}

The AV-fistula rat model. AV-fistula surgery was performed on male Wistar rats (Bantam and King, Hull, UK) weighing 260-280 g, anesthetized with Hypnorm ( $1 \mathrm{ml} / \mathrm{kg}$ administered intraperitoneally; Janssen Pharmaceuticals Ltd., Oxford, UK). A midline celiotomy was performed and the intestines were displaced laterally. The aorta and the inferior vena cava were exposed and clamped. A fistula (1-1.5 mm) was made with scissors through a side-to-side anastomosis between these two vessels $\sim 10 \mathrm{~mm}$ distal to the renal arteries. In the control sham-operated rats, the aorta and the inferior vena cava were exposed and temporarily clamped for $\sim 5$ min without cutting or suturing the blood vessels. After recovery from the anesthetic, the animals were placed in cages with free access to water and standard rat laboratory diet. The mortality rate of the surgical procedure was $12 \%$.

Tissue preparation. At 7, 21, 28, 35, and $49 \mathrm{~d}$, the AV fistula animals were anesthetized with Hypnorm and the hearts were removed quickly, weighed, and placed on ice. To conserve the number of animals employed, we elected to study two groups of control rats at 7 and $35 \mathrm{~d}$. Four animals were used for each experimental time point. Both atria (right atrium, RA; left atrium, LA) were carefully dissected off and the right ventricle (RV) was cut flush from the septum and the left ventricle (LV). All four chambers were weighed separately. Samples were then frozen in liquid nitrogen and maintained at $-80^{\circ} \mathrm{C}$ until used for mRNA extraction.

$m R N A$ extraction. mRNA was isolated from $\sim 25 \mathrm{mg}$ of atrial or ventricular myocardium using the Microfast Track mRNA Isolation Kit (Invitrogen, San Diego, CA), which employed oligo(dT) cellulose to adsorb polyA ${ }^{+}$mRNA. Nonpolyadenylated RNA, DNA, dissolved membranes, proteins, and cellular debris were washed off the resin with the high salt buffer supplied, and tRNA and rRNA with the low salt buffer. The mRNA was then eluted in the absence of salt and stored in ethanol at $-80^{\circ} \mathrm{C}$. After ethanol precipitation the mRNA was resuspended in $10 \mu$ l of nuclease-free water.

Dot blot hybridization of $m R N A .2 \mu \mathrm{l}$ of each mRNA sample was dotted, in duplicate, onto a nylon membrane (Hybond-N; Amersham International plc, Amersham, UK). After a prehybridization step, the membranes were hybridized overnight at $37^{\circ} \mathrm{C}$ in a solution containing $50 \%$ Formamide, $50 \mathrm{mM} \mathrm{NaH}_{2} \mathrm{PO}_{4}, \mathrm{pH} 7.0,5 \mathrm{mM}$ EDTA, $0.9 \mathrm{M}$ $\mathrm{NaCl}, 5 \times$ Denhardt's solution, $0.1 \% \mathrm{SDS}$, and $100 \mu \mathrm{g} / \mathrm{ml}$ salmon sperm DNA and $64 \mathrm{pmol}\left(62.5 \times 10^{6} \mathrm{cpm}\right)$ of a 30 -base oligo-dT probe which had been 5 '-end-labeled with T4 polynucleotidyl kinase and [ $\gamma$ ${ }^{32} \mathrm{P}$ ]ATP ( $>5,000 \mathrm{Ci} / \mathrm{mmol}$; Amersham International plc). The labeled probe had been separated from unincorporated nucleotides by passage through Sephadex G-50 (Pharmacia, Milton Keynes, UK). The membranes were then washed with increasing stringency (down to $20 \mathrm{mM} \mathrm{Na}^{+}+0.1 \% \mathrm{SDS}$ ) at $37^{\circ} \mathrm{C}$, and exposed to autoradiography film. Each dot was cut from the membrane and the amount of probe hybridization was measured by liquid scintillation counting (Tri-carb
2000CA Liquid Scintillation Analyzer; United Technologies Packard, Pangbourne, UK).

$R T$. 2- $\mu$ l aliquots of mRNA were reverse transcribed with $25 \mathrm{pmol}$ of a 12-mer random sequence primer and $10 \mathrm{U}$ Moloney murine leukemia virus reverse transcriptase (Pharmacia) in the buffer recommended by the supplier. The reaction tubes were then incubated at $37^{\circ} \mathrm{C}$ for $2 \mathrm{~h}$. After this, the cDNA samples were diluted with nucleasefree water to a volume of $100 \mu \mathrm{l}$.

PCR amplification of $c D N A s$. PCR was performed using $2.5 \mu \mathrm{l}$ of the diluted cDNA sample in a total reaction volume of $25 \mu$ l. Master PCR mixes ( $17.5 \mu$ l per tube) were prepared with pairs of primers specific for ANP, BNP, NPR-A, NPR-B, NPR-C, or glyceraldehyde3-phosphate dehydrogenase (G3PDH) (Table I). The final reaction concentrations were as follows: $1 \mu \mathrm{M}$ primers, $50 \mathrm{mM} \mathrm{KCl}, 10 \mathrm{mM}$ Tris- $\mathrm{HCl}$ ( $\mathrm{pH} 9.0$ ), $1.5 \mathrm{mM} \mathrm{MgCl}_{2}, 0.01 \%$ Triton X-100, $50 \mu \mathrm{M}$ deoxynucleotides, and $0.02 \mu \mathrm{Ci} / \mu \mathrm{l}$ of $\left[\alpha{ }^{32} \mathrm{P}\right] \mathrm{dCTP}(>5,000 \mathrm{Ci} / \mathrm{mmol}$; Amersham International plc). The reactants were overlaid with mineral oil. 1 U of Taq DNA polymerase (Promega Corp., Madison, WI) in $5 \mu \mathrm{l}$ of nuclease-free water was added to the reaction tubes during a 3 min incubation at $95^{\circ} \mathrm{C}$ ("hot start" method). PCR was performed for $19-40$ cycles $\left(93^{\circ} \mathrm{C}\right.$ for $30 \mathrm{~s}, 55-60^{\circ} \mathrm{C}$ for $30 \mathrm{~s}, 73^{\circ} \mathrm{C}$ for $60 \mathrm{~s}$; final extension at $73^{\circ} \mathrm{C}$ for $10 \mathrm{~min}$ ).

Analysis of PCR products. We have assessed the relative amounts of template cDNA at the start of the PCR by measuring the amount of DNA product during the exponential phase of amplification. The conditions necessary for exponential amplification with each primer pair were achieved by altering the number of PCR cycles or by dilution of the initial cDNA template. For each set of primers, cDNA samples from both control and hypertrophied hearts were amplified for 19-40 cycles to determine the range over which exponential amplification was occurring. A cycle number was chosen to allow all the reactions for a particular template to be amplified together; the cDNA samples were diluted if necessary.

For each of the time points, four rats were used. cDNAs from the four cardiac chambers of each animal were amplified in duplicate, except for those used to measure the intraassay coefficient of variation (CV).

$15 \mu \mathrm{l}$ of each PCR product was separated by electrophoresis through a nondenaturing $6 \%$ polyacrylamide gel using TBE buffer (45 $\mathrm{mM}$ Tris borate, $1 \mathrm{mM}$ EDTA). The gels were exposed to autoradiography film to locate the specific product bands (of the expected size) on the gel. The gel band was then excised and the amount of ${ }^{32} \mathrm{P}$ incorporated into the amplification product was quantified by liquid scintillation counting. In the case of NPR-B a second major product was observed which was slightly smaller. In that it may represent cDNA from an alternatively spliced mRNA, both bands were included for quantification.

For each cDNA sample, the counts (in $\mathrm{cpm}$ ) incorporated into the amplification fragment were then divided by the mRNA counts for the same sample (in cpm) derived from the dot blots. This corrected for variation in the extraction of mRNA.

Statistical analysis. The statistical significance of the changes in transcript levels in each cardiac chamber during the development of cardiac hypertrophy was determined by one-way ANOVA using the statistical program, Statgrafics (Statistical Graphics Corp., Rockville, MD). The significance of a difference was then determined by individual unpaired $t$ tests. The significance of a correlation between two variables was determined by linear regression analysis using the graph-plotting programme, Fig P (Biosoft Ltd., Cambridge, UK). $P<0.05$ was considered to be statistically significant.

\section{Results}

\section{Development of cardiac hypertrophy in AV fistula rats}

The chronic volume overload produced by the AV fistula resulted in significant progressive hypertrophy (as determined by the ratio of chamber weight to body weight) of all the cardiac chambers from 7 up to $28 \mathrm{~d}$ (Fig. 1). After this time there were 


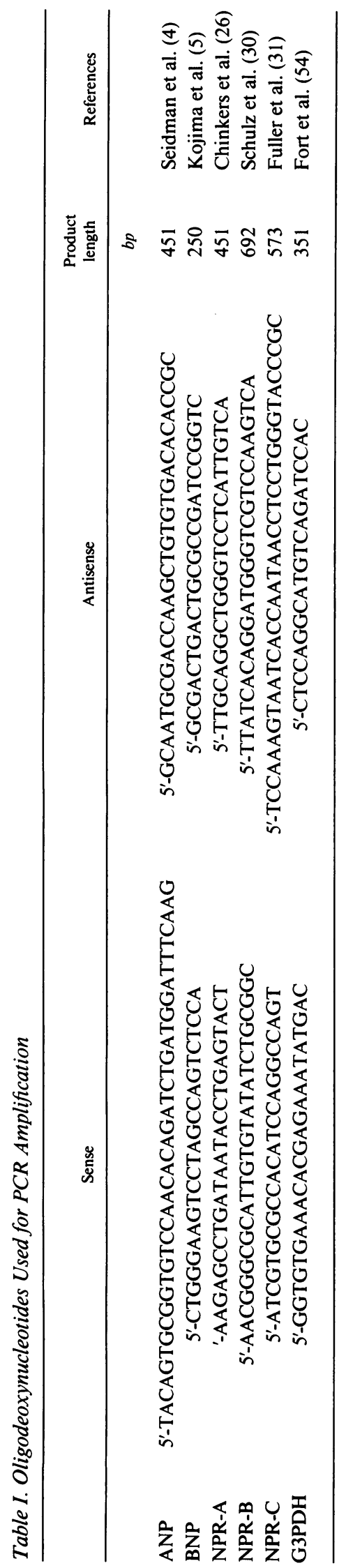

no further significant increases in cardiac chamber weights. This contrasted clearly with the growth characteristics of the control rat hearts in which the increase in chamber weight from 7 to $35 \mathrm{~d}$ paralleled the rise in body weight (i.e., there was no change in the cardiac chamber weight/body weight ratio).

\section{Validation of the PCR assay}

$m R N A$ dot blot analysis. A 10-fold variation in mRNA extraction efficiency was observed using the Microfast Track method (data not shown). There was a significant positive correlation ( $r=0.55, P<0.001$ ) between the mean of the oligo-dT probe hybridization to the two dot blots of a mRNA and the quantity of G3PDH DNA produced by amplification of the cDNA from that particular mRNA (data not shown).

Characterization of the efficiency of amplification. The effect of altering the degree of amplification on the amount of specific product was assessed by varying the number of PCR cycles (19-40 cycles). Representative cDNA samples from control and hypertrophied hearts were used. Fig. 2 shows the cycling curves used to determine the exponential phase of amplification for each of the cDNA templates. The following cycle numbers were chosen for all further analyses: ANP 30 cycles, BNP 28 cycles, NPR-A 36 cycles, NPR-B 38 cycles, NPR-C 36 cycles, and G3PDH 29 cycles. For ANP amplification, the control atrial cDNAs were diluted 10 -fold, and the AV fistula atrial cDNAs 20-fold.

When transformed into log-linear plots, the cycling curves were used to determine the efficiency of the amplification process during the exponential phase using the equation: $\log Y$ $=\log A+n \log (1+R)$, where $R$ is the efficiency, $A$ the initial amount of DNA, and $Y$ the extent of amplification (55). For the six templates, an average efficiency of $60 \%$ per cycle was observed over the exponential range.

Specificity. After amplification, a single DNA band of the predicted size was observed using the cDNA samples and primers specific for G3PDH, ANP, BNP, NPR-A, and NPR-C (Fig. 3). Two major products of similar size were generated with the NPR-B primers.

The primers employed in these experiments had been evaluated previously by subjecting the amplified DNA to Southern blotting, restriction enzyme cleavage, or DNA sequencing to establish the specificity of the products generated by PCR (51, 56 and D. J. Nunez, unpublished results). Moreover, there are differences in the effects of cardiac hypertrophy on the prevalence of the transcripts for ANP, BNP, NPR-A, NPR-B, NPRC, and G3PDH as detected by RT-PCR (Figs. 4 and 5). Amplification with the G3PDH primers provides a baseline for comparison with other results. Atrial and ventricular G3PDH mRNA prevalence was measured using the cDNA samples from control and hypertrophied hearts (Fig. 4). Overall, there appeared to be a trend for the G3PDH mRNA to increase with time (two- to fourfold change), but this was only significant in the LV samples at $28 \mathrm{~d}(P<0.05), 35 \mathrm{~d}(P<0.005)$ and $49 \mathrm{~d}$ $(P<0.05)$. There was no significant correlation between the individual chamber weights and the G3PDH mRNA prevalence.

Sensitivity. We have attempted to obtain a measure of the sensitivity of the RT-PCR technique by studying the expression of the NPR-B mRNA in the heart, inasmuch as it has not been detected by in situ hybridization ( 50 ), a technique which is more sensitive than Northern blotting (57). Fig. 2 clearly demonstrates the presence of these transcripts in samples of 

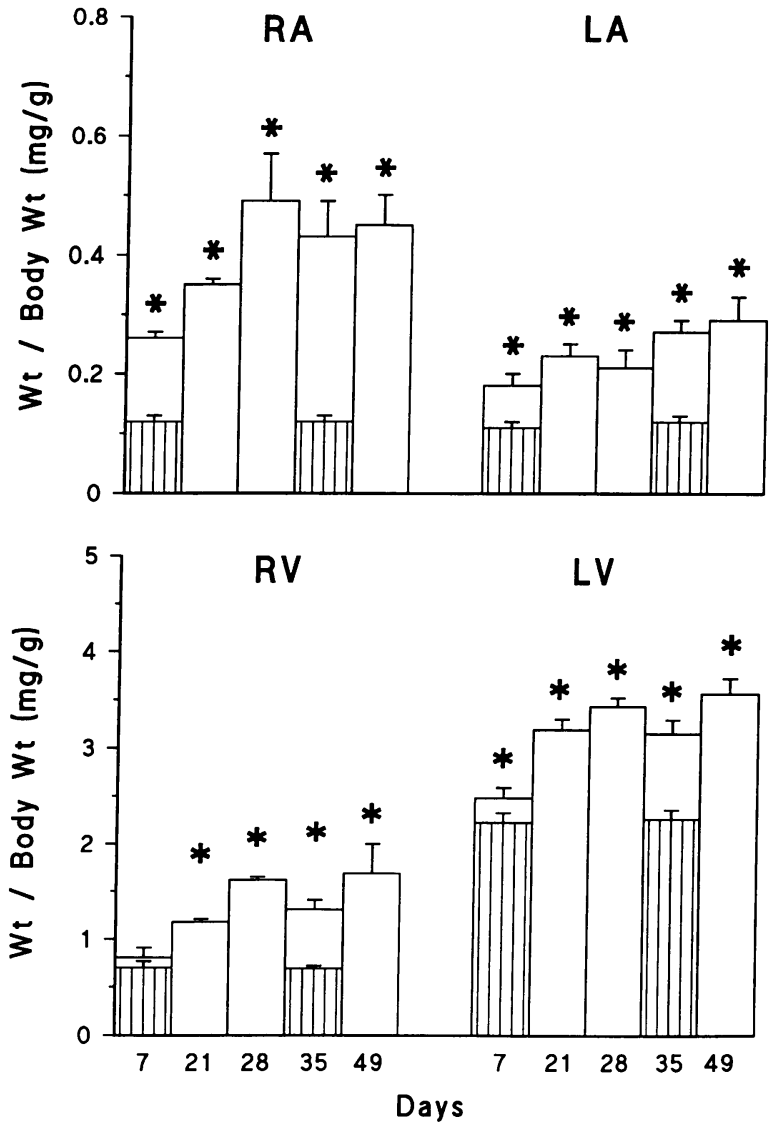

Figure 1. Time course of cardiac hypertrophy in rats with AV fistulae and in sham-operated controls. In the AV fistula rats (open columns), there was progressive hypertrophy of all cardiac chambers with time. In the 7- and 35-d sham-operated controls (hatched columns), there was no change in the cardiac chamber weight relative to body weight. Values are expressed as the ratio of the chamber weight $(\mathrm{mg})$ divided by the body weight $(\mathrm{g})($ mean $\pm \mathrm{SEM} ; n=4$ rats $) .{ }^{*} P<0.01$ or less compared to sham-operated values.

cDNA derived from the equivalent of $\sim 125 \mu \mathrm{g}$ (wet weight) of tissue.

Reproducibility. Due to the exponential nature of PCR amplification, small differences in any of the variables, such as the amount of initial mRNA template or the efficiency of cDNA synthesis, may greatly affect the amount of DNA produced. For this reason we have paid particular attention to the reproducibility of the assay. Even though we employed approximately the same weight of tissue for mRNA extraction, the large variation $(\sim 10$-fold $)$ in extraction efficiency observed with the oligo-dT dot hybridization made it necessary to introduce a correction for these differences. The intraassay $\mathrm{CV}$ of the whole quantification procedure was $5.8 \%$ when five mRNA aliquots derived from a single control LV mRNA sample were reverse transcribed and then amplified using the G3PDH primers. A separate experiment yielded a CV of $8.5 \%$ when five aliquots from a single control RA cDNA were amplified with the ANP primers. All the samples used to measure a particular cDNA template were performed in a single experiment to avoid interassay variability.

Accuracy. In the absence of a fully validated alternative technique for measuring specific mRNA transcripts, we have assessed the accuracy of this RT-PCR method by measuring the prevalence of ANP and BNP mRNA, since there is some data to indicate the relative levels of atrial and ventricular expression and the changes occurring during the development of cardiac hypertrophy. In control rat hearts, ANP mRNA levels were greater in the atria than the ventricles (e.g., RA/RV ratio $=25$ ). Fig. 4 shows how corrected mean ANP mRNA prevalence changed during the development of cardiac hypertrophy. The levels rose significantly in both atria up to $21 \mathrm{~d}$ (a 14-fold increase in RA, $P<0.001$; and a 62 -fold increase in the LA, $P$ $<0.01$ ), and then fell-levels were not significantly different from baseline by $49 \mathrm{~d}$. In the ventricles on the other hand, there was a much slower, but progressive, trend towards a rise in ANP transcript prevalence, but this only reached significance at $28 \mathrm{~d}$ in the LV (13-fold increase; $P<0.05$ ). Interestingly, although not reaching statistical significance because of the large amount of variation, at $49 \mathrm{~d}$ there was a 150 -fold increase in the RV $(R A / R V$ ratio $=0.85)$ and a 15-fold increase in the LV.

In control rats, BNP mRNA levels were similar in the atria and ventricles (Fig. 4). Although there was a trend towards a rise in the RA, the changes did not achieve statistical significance. The pattern of expression in the LA during the development of hypertrophy was similar to that seen with ANP mRNA. BNP transcript prevalence increased significantly up to $21 \mathrm{~d}$ ( 18 -fold increase; $P<0.01$ ). The level then declined steadily towards baseline control values. In the $\mathrm{RV}$, transcript prevalence remained unchanged (at $49 \mathrm{~d}$ there was a 10 -fold rise, but this did not achieve statistical significance). In the LV, there was no significant change in transcript prevalence, but there was a trend toward an increase (3- to 4-fold above baseline at $49 \mathrm{~d}$ ). In all cardiac chambers, there were no differences in the expression of ANP and BNP mRNA between the control sham-operated 7- and 35-d animals (data not shown).

\section{NPR transcript levels during the development of cardiac hypertrophy}

Fig. 3 shows typical DNA products obtained from PCR reactions using NPR-A, NPR-B, and NPR-C primers and CDNA samples from control and hypertrophied hearts. The most striking observation was the contrast between the change in prevalence of the NPR-A and NPR-B transcripts when compared to the alteration in NPR-C mRNA, during the development of cardiac hypertrophy (Fig. 5).

In control rat hearts, NPR-A mRNA levels were similar in the atria and ventricles. During the development of hypertrophy, the RA showed a trend toward an increase in NPR-A mRNA prevalence (7-fold change), but this did not achieve statistical significance. In the LA the prevalence increased steadily, reaching a level at $49 \mathrm{~d}$ which was 24 times greater than the control value $(P<0.01)$. In the ventricles, NPR-A mRNA reached a peak at $28 \mathrm{~d}(10$-fold increase in $\mathrm{RV}, P$ $<0.01$; 19 -fold rise in $\mathrm{LV}, P<0.005$ ), after which there was a decline toward baseline. There was a significant positive correlation between chamber weight and NPR-A mRNA levels in the LA (up to $49 \mathrm{~d}, r=0.5, P<0.02$ ), the RV (up to $28 \mathrm{~d}, r$ $=0.72, P<0.002$ ) and the LV (up to $28 \mathrm{~d}, r=0.85, P$ $<0.001$ ).

The prevalence of NPR-B mRNA transcripts in control rat hearts were comparable in the atria and the ventricles. In all the chambers, except the RA, there was a progressive increase in mRNA prevalence which peaked at $28 \mathrm{~d}$ (30-fold increase in LA, $P<0.005$; 70-fold increase in RV, $P<0.005$; 60-fold 

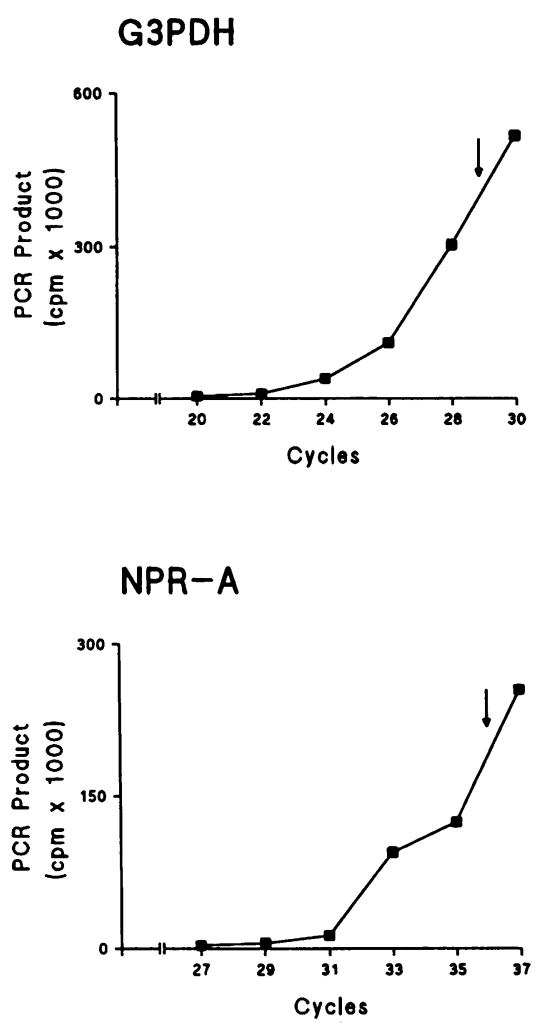

ANP

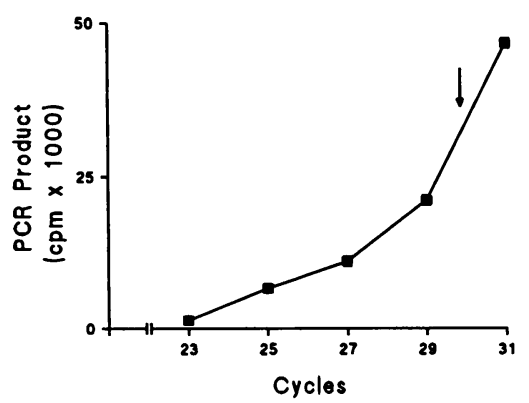

NPR-B

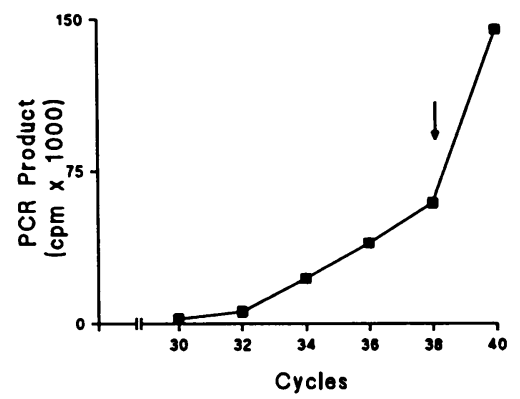

BNP

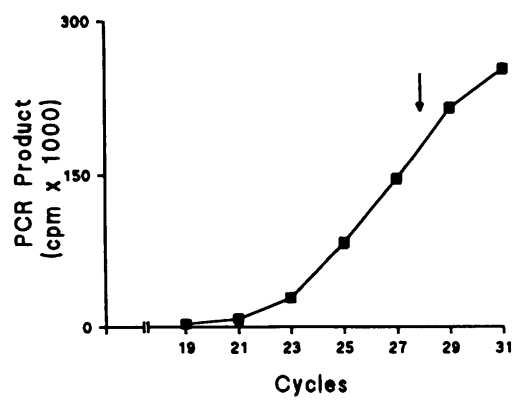

NPR-C

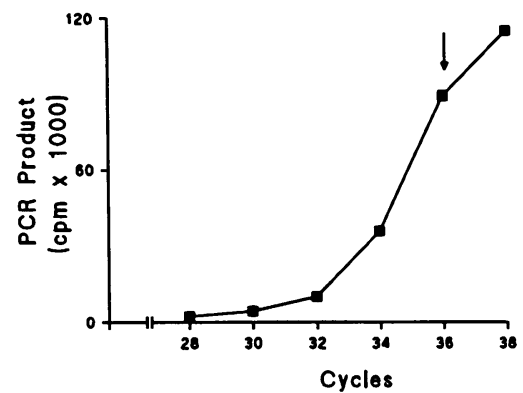

Figure 2. The effect of altering the number of PCR cycles on the yield of cDNA product. Amplification of cDNAs from representative control (ANP, sham RA; NPR-C, sham RV) and hypertrophied cardiac chambers (G3PDH, 21-d LA; BNP, 35-d RA; NPR-A, 21-d RA; NPR-B, 28-d RA) was performed for 19-40 cycles. For the ANP amplifications, the cDNAs were diluted 10-fold. After exposure to autoradiographic film, the specific DNA product bands were excised and quantified by liquid scintillation. The amount of ${ }^{32} \mathrm{P}$ incorporated into the specific DNA product at each level of amplification was used to construct a cycling curve for each of the transcript templates. The small arrow above each curve indicates the cycle number that was chosen for all subsequent amplifications utilizing the particular pair of primers.

increase in $\mathrm{LV}, P<0.002$ ), after which they fell to control levels (Fig. 5). Although, there was a trend toward a rise in NPR-B mRNA in the RA, this did not achieve statistical significance. There was a significant positive correlation between chamber weight and NPR-B mRNA levels during the development of cardiac hypertrophy in all four chambers up to $28 \mathrm{~d}$ (atria $r=0.6, P<0.05$; ventricle $r=0.88, P<0.001$ ). The autoradiographic appearances indicated that, in general, the relative prevalence of the two NPR-B amplification products did not vary during the course of these experiments. However, we did not establish the optimal amplification parameters for each NPR-B cDNA in isolation.

There were a number of prominent differences between the expression of NPR-C transcripts and those of the guanylyl cyclase receptors. The level of NPR-C mRNA in control hearts was significantly greater in the RA compared with the other chambers (RA 79 \pm 9 ; LA 23 \pm 2 ; RV 42 \pm 17 ; LV 20 \pm ; $P$ $<0.005)$. In marked contrast to the patterns of expression of the guanylyl cyclase receptors, which were readily detectable throughout the study period, the prevalence of NPR-C mRNA fell progressively during the development of cardiac hypertrophy (Fig. 4). The transcripts were undetectable in all chambers by $28 \mathrm{~d}$, when the prevalence of NPR-A and NPR-B mRNA was greatest. Augmenting the degree of amplification by increasing the number of PCR cycles for the 28-, 35-, and 49-d cDNAs produced weak specific DNA bands in some, but not in other samples. In the samples in which the specific NPR-
C product was not detectable no other competitive template bands were observed.

The changes in NPR-C prevalence during the development of cardiac hypertrophy were not observed during normal growth of the rats. In the 35-d control rats, NPR-C transcripts were detectable at levels which were not significantly differently from those at $7 \mathrm{~d}$ (data not shown).

\section{Discussion}

Our studies of the prevalence of NPR mRNAs in the rat heart during the development of cardiac hypertrophy provide the first demonstration ex vivo of their differential regulation and kinetics of expression. In the AV fistula rat, progressive and marked hypertrophy affecting all the cardiac chambers was accompanied by significant increases in ANP mRNA prevalence throughout the heart; in contrast, BNP mRNA was elevated only in the LA. The most remarkable observation, however, was the gradual disappearance of NPR-C transcripts (the putative "clearance" receptor) which differed strikingly from the increase in mRNA levels for both NPR-A and NPR-B (the guanylyl cyclase-linked receptors).

Messenger RNA quantification was performed using the technique of cDNA amplification by PCR (RT-PCR). A major advantage of this technique is that it allowed us to follow changes in the prevalence of six transcripts within a single small cDNA sample. This would not have been possible using more 


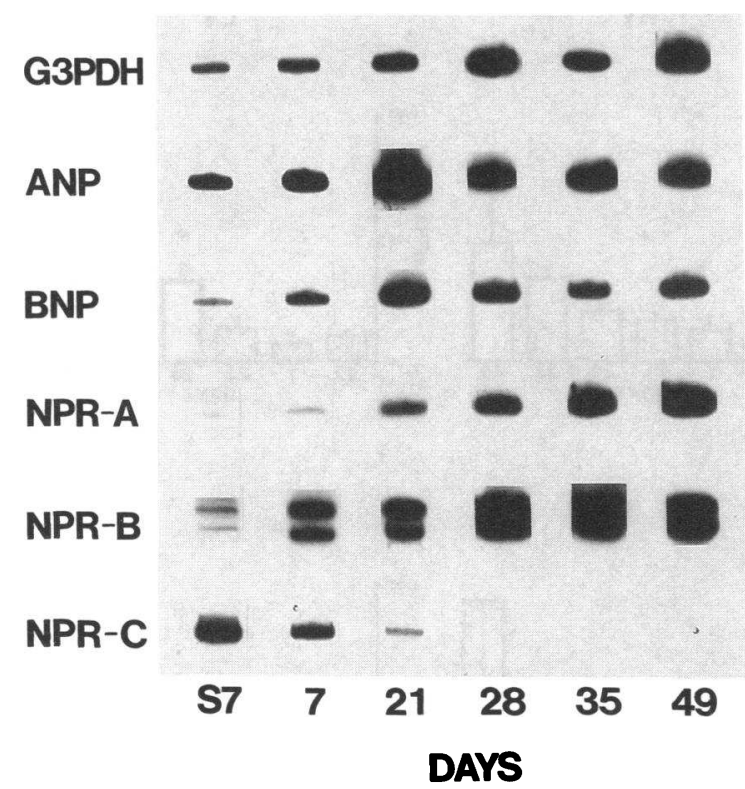

Figure 3. Amplification of right atrial cDNAs from sham-operated and $A V$ fistula rats with primer pairs for G3PDH, ANP, BNP, NPR$A$, NPR-B, and NPR-C. cDNAs from the RA of 7-d sham-operated and 7-49-d AV fistula rats were amplified by RT-PCR using the specific primer pairs shown in Table I at the cycle number chosen for exponential amplification (G3PDH 29 cycles, ANP 30 cycles, BNP 28 cycles, NPR-A 36 cycles, NPR-B 38 cycles, NPR-C 36 cycles). For ANP amplification, the control atrial cDNAs were diluted 10 -fold and the AV fistula atrial cDNAs were diluted 20-fold. After separation by PAGE, the gel was exposed to autoradiography film. DNA bands of the predicted size were obtained ( $451 \mathrm{bp}$ for ANP, $250 \mathrm{bp}$ for BNP $451 \mathrm{bp}$ for NPR-A, $573 \mathrm{bp}$ for NPR-C, $309 \mathrm{bp}$ for G3PDH). For NPR-B two bands were seen: the expected product at $692 \mathrm{bp}$ and also a smaller DNA which may represent DNA derived from a truncated, alternatively spliced NPR-B mRNA. The relative amounts of the two NPR-B DNAs did not appear to vary during the time course of these experiments.

conventional methods for quantifying mRNAs, such as membrane hybridization and RNAase protection assays, since there would be insufficient extractable RNA from individual cardiac chambers, particularly the atria, to detect relatively rare transcripts.

It is recognized that PCR-based methods have limitations as quantitative assays. Principal among these is that PCR may amplify small differences in the amount of initial mRNA template or the efficiency of cDNA synthesis. One method advocated to overcome this problem is "competitive PCR," in which serial dilutions of a standard template are co-amplified with the template whose concentration is unknown. In this study incorporation of dilution curves of the standard for each cDNA sample would not have been practicable without increasing technical variability because of the large number of samples involved. Instead we elected to quantify the cDNAs by a simpler method which relies on the measurement of the specific product during the exponential phase. This is similar in concept to immunological titration assays (but with a doubling of the product at each cycle rather than serial dilution) and must be regarded as semiquantitative in its dynamic response. Nonetheless, this was sufficient to define patterns of response and identify differences in expression between the transcripts measured.
The specificity of the method is an important consideration and can be judged in two ways. First, in our previous published $(51,56)$ and unpublished studies the following criteria have established the identity of the DNA bands produced by amplification with the primers used here: $(a)$ except for the NPR-B doublet amplification product, all the other PCR DNAs have been single and clearly distinguishable from smaller minor products; $(b)$ they are of the predicted size; $(c)$ they are cleaved by restriction endonucleases at the expected sites; $(d)$ they hybridize with appropriate oligonucleotide probes which are flanked by the PCR primers, and $(e)$ the product has been sequenced if amplification has been performed with primers designed from the sequence of the cDNA of another species (e.g., NPR-C; 51 ). Secondly, we are reassured of the specificity of our method by the different trends in expression of the six transcripts during the development of cardiac hypertrophy. The transient increase in ANP, BNP, NPR-A, and NPR-B mRNA levels contrasts with the progressive disappearance of NPR-C mRNA and the small rise of G3PDH mRNA. This indicates that we are not detecting general changes in mRNA content.

Generally, methods based on PCR can be relied upon to exhibit much lower limits of detection than other quantitative methods such as Northern blotting and RNAase protection. Indeed, it is a requirement to establish that the sensitivity of the PCR assay is not so great as to detect "illegitimate" transcripts $(55,58,59)$ which would be of little pathophysiological significance. Our data on the NPR-C transcript show that this is not the case, since this mRNA was not detectable at and beyond 28 $\mathrm{d}$, when the other transcripts were easily observed. Furthermore, we have been unable to detect consistently CNP mRNA transcripts in the cDNAs from our control and AV fistula rat hearts (L. A. Brown, unpublished observations).

Our measurements of ANP mRNA prevalence in cardiac tissue compare favorably with published data. The atrioventricular differences in ANP mRNA levels we observed in the hearts of sham-operated rats ( $\sim 20$-fold greater in the atria) are consistent with previous reports in which these have ranged from 10-fold (PCR-based method [60]) to 50-fold (detected by RNA hybridization methods [61, 62]). Cardiac hypertrophy in the AV fistula rat was associated with a 17- to 62-fold increase in cardiac ANP mRNA levels after $21 \mathrm{~d}$. In a subset of Wistar rats that develop spontaneous biventricular hypertrophy a 6-fold increase in ventricular ANP mRNA has been recorded (63). A 3-fold increase in ANP mRNA has been noted in the hearts of animals subjected to aortic banding $7 \mathrm{~d}$ previously (measured by membrane hybridization) (64), and a 6- to 10-fold rise in these transcripts in $14 \mathrm{~d} \mathrm{AV}$ fistula rats (quantified by nuclease protection assays) $(62,65)$. After the initial rapid increase of atrial mRNA levels up to $21 \mathrm{~d}$, there was a trend to decline from $28 \mathrm{~d}$ onwards. A reduction in plasma ANP levels after an early peak has been reported recently in AV fistula rats ( 53), and provides support for a correlation between myocardial mRNA prevalence and plasma ANP concentration, as found by others (e.g., 66, 67).

Changes in BNP mRNA in hypertrophied myocardium have not been extensively studied. Here we report that BNP transcript prevalence was augmented significantly only in the hypertrophied left atrium. This discrepancy in the response to hypertrophy between ANP and BNP is consistent with the hypothesis that the hypertrophied myocyte regresses back to a phenotype with fetal characteristics (68). In fetal and neonatal 
G3PDH
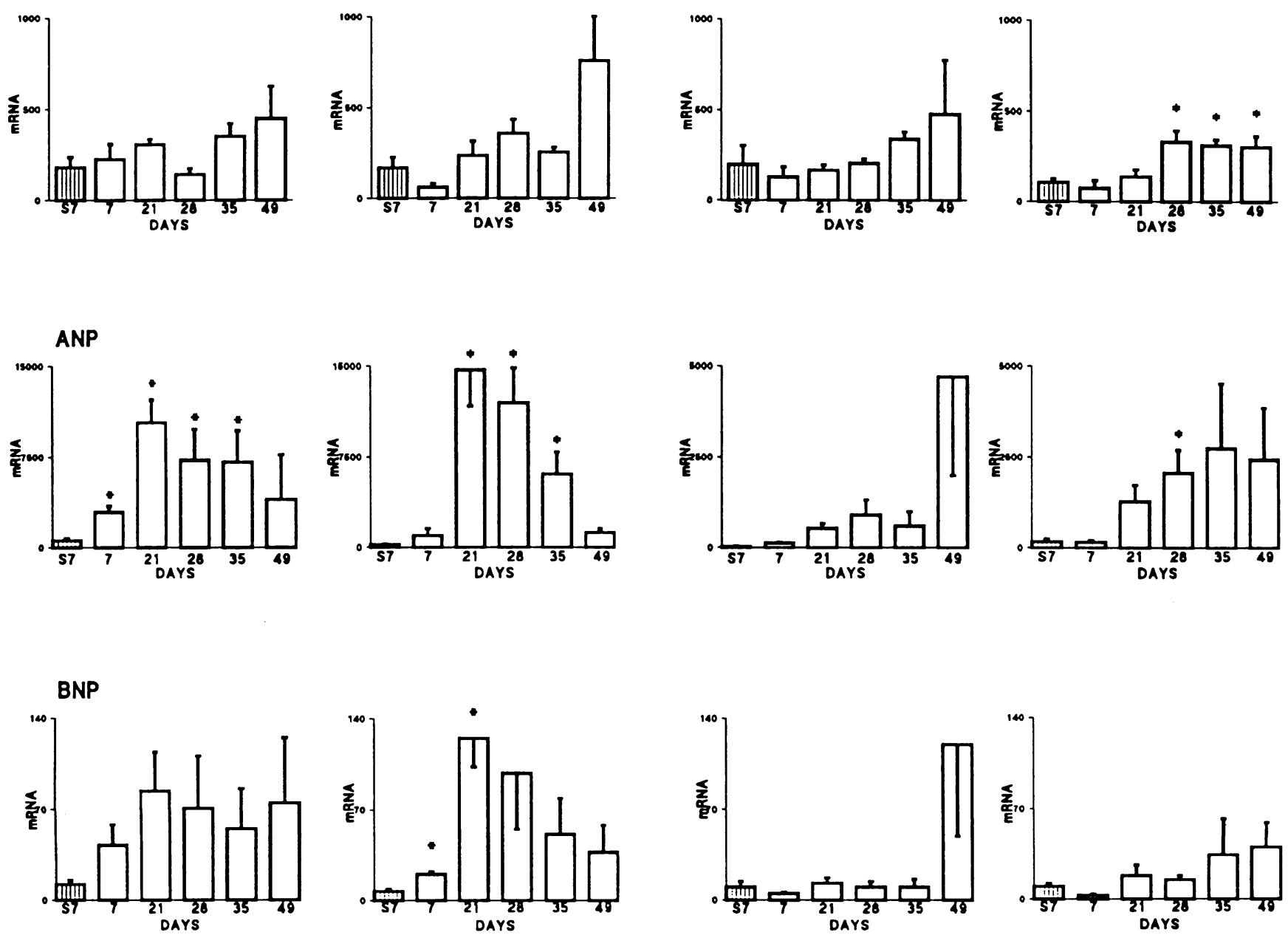

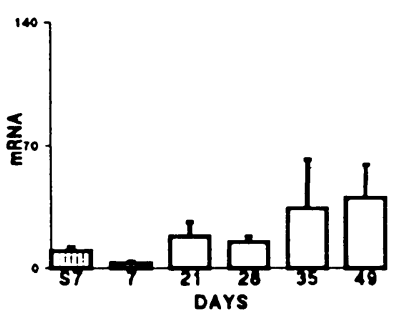

Figure 4. The expression of G3PDH, ANP, and BNP transcripts during the development of cardiac hypertrophy. Specific primer pairs were utilised to amplify cDNAs from the cardiac chambers of AV-fistula rats (open columns) and sham-operated rats ( $S 7$, hatched columns). The amount of radioactivity ( mean \pm SEM; $n=4$ rats) in each DNA band was corrected for variation in mRNA extraction (i.e., cpm of the specific DNA band/cpm of the mRNA dot blot). Myocardial hypertrophy was accompanied by increased ANP mRNA prevalence throughout the heart and increased BNP mRNA in the left atrium. ${ }^{*} P<0.05$ or less when compared with the $7-\mathrm{d}$ sham-operated values.

hearts, ANP mRNA levels are much higher than in adult myocardium $(57,69-71)$, whereas there is little difference in the expression of BNP mRNA (69). In contrast, the BNP system is activated greatly by heart failure (69). Perhaps ANP may function to keep in check the extent of cardiac hypertrophy by activating antihypertrophic mechanisms similar to the antiproliferative effects seen in smooth muscle cells (24). It is interesting to speculate that the loss of NPR-C mRNA (and presumably the receptors themselves) from the heart may be an adaptive response which enhances this action of ANP. BNP, on the other hand, may have a more "conventional" role in reducing the volume load on a failing heart by enhancing salt and water excretion.

In a previous paper we reviewed the evidence for the existence of NPR in the heart (51). Here we have extended these studies to determine how these transcripts are modulated in the AV fistula rat. This is a well-established model of cardiac hypertrophy in which plasma ANP levels are elevated chronically $(52,53,72,73)$. The myocardial remodeling observed in these animals is similar to that seen with other manoeuvres producing hypertrophy (74-76). The experimental protocol is well established in our department and provides animals in which the rate and extent of hypertrophy is very reproducible.

There is evidence that the number of NPR on platelets (77), in blood vessels (78), and in the kidney (79) is altered in patients and animal models with elevated circulating ANP concentrations. Our studies of a single human heart had already suggested that the regulation of the guanylyl cyclase receptor mRNAs (NPR-A and NPR-B) might be different to that of the NPR-C mRNA (51). This is clearly demonstrated by the results in Fig. 5. We observed increases in both NPR-A and NPR-B mRNA prevalence during the development of cardiac hypertrophy which contrasted with the progressive decline in NPR-C mRNA levels. This fall in the amount of specific NPR$\mathrm{C}$ product was not due to the appearance of competitive templates during the process of hypertrophy. The changes in these mRNAs seen in AV fistula rats did not occur during the normal growth of the heart (cf. 7- and 35-d sham-operated rat 
NPR-A
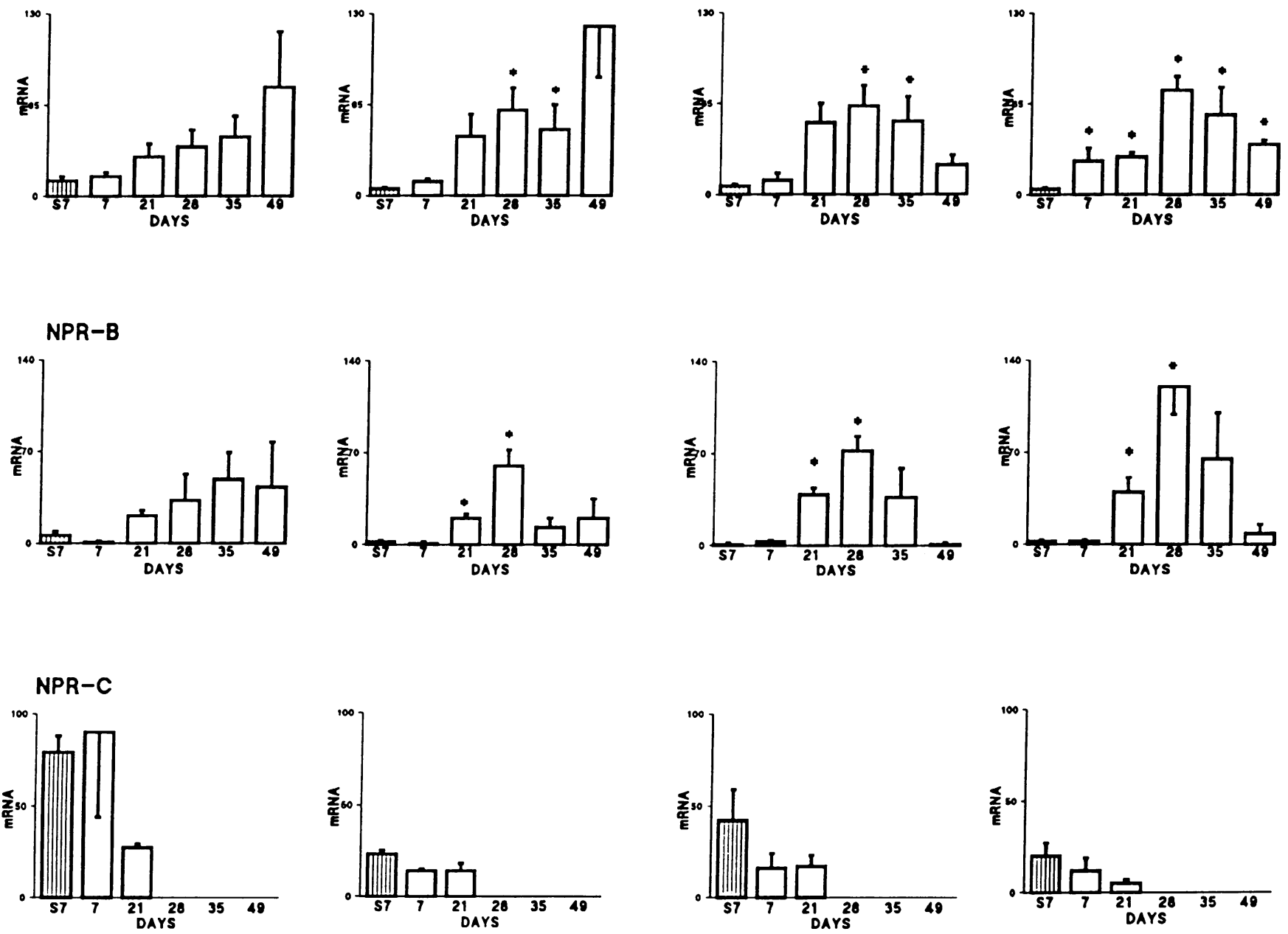

Figure 5. The change in prevalence of NPR-A, NPR-B, and NPR-C mRNAs during the development of cardiac hypertrophy. NPR mRNAs were quantified by RT-PCR using specific primer pairs and CDNAs from cardiac chambers of AV fistula rats (open columns) and sham-operated rats (S7, hatched columns). The amount of radioactivity ( mean $\pm \mathrm{SEM} ; n=4$ rats) in each DNA band was corrected for variation in mRNA extraction (i.e., cpm of the specific DNA band/cpm of the mRNA dot blot). There was a gradual, but striking, disappearance of NPR-C transcripts in all chambers during the development of cardiac hypertrophy. At the same time there was a transient increase in mRNA levels for both NPR-A and NPR-B. ${ }^{*} P<0.05$ or less when compared with the $7-\mathrm{d}$ sham-operated values (mean $\pm \mathrm{SEM} ; n=4$ rats).

hearts), indicating that the differences in the transcript levels are related to the development of hypertrophy of the myocardium. We have not attempted to compare in detail the level of each receptor transcript at any particular time point, since different degrees of amplification were employed. However, it would appear that the prevalence of NPR-B mRNA is lower than that of the other two receptors.

We have not established the nature of the second major NPR-B PCR product, which has not been detected previously (51). On occasions we have observed a similar phenomenon when amplifying human and rat cDNA with NPR-C primers $(80)$. It is likely that these smaller DNA products have arisen from truncated cDNAs generated by reverse transcription of alternatively spliced mRNA. In general the relative abundance of the two NPR-B products did not change during the time course of these experiments, as was observed by Mizuno and colleagues ( 81 ) with two putative alternative transcripts arising from the bovine NPR-C gene. Ohyama et al. (82) have characterized two NPR-B cDNA clones from rat brain which differed by $75 \mathrm{bp}$ close to the intracellular kinase-like domain. The latter is adjacent to the guanylyl cyclase domain. When expressed on mammalian cells, the two forms of NPR-B possessed similarly high-binding affinity for CNP, but guanylyl cyclase activity was not observed with the truncated form. The two NPR-B products we have observed indicate the existence of a different splice variant since the primers are directed to sequences in the extracellular domain of the receptor.

The exact location in the heart of the NPR mRNAs detected in this study is unknown, since whole pieces of myocardium were used for extraction. Previous studies have shown that the receptors are located primarily on the endocardial endothelium using receptor autoradiography $(45,83)$, although NPR-C mRNA has also been detected throughout the right atrium by in situ hybridization ( 50 ). The direct pharmacologi- 
cal effects of ANP on isolated myocytes (43-45) would indicate that these receptors are also expressed by muscle cells themselves.

NPR-C has been postulated to be involved in the clearance of circulating natriuretic peptides (40-42). It has less stringent ligand requirements than either NPR-A or NPR-B, binding ANP, BNP, and CNP with approximately equal affinity. In the AV fistula rats, circulating ANP concentrations are elevated (53) and are associated with a reduction in NPR-C mRNA in the heart. One might expect a clearance receptor to be turning over more rapidly when plasma ANP levels are high, and the prevalence of the mRNA for the receptor to rise pari passu. On the other hand, the stimulus that leads to greater ANP secretion may also reduce the number of clearance receptors, thus enhancing the biological response to the peptide. Changes in NPR-C number on endothelial cells have been shown to be accompanied by reductions in NPR-C mRNA levels (84), suggesting that the alteration in transcript levels we observed actually represent a decrease in the number of receptor proteins. This would agree with evidence that the latter are less abundant when plasma ANP is increased $(77,78)$. Our data can also be interpreted as being consistent with receptor "down-regulation" of the type characteristic of functional receptors, such as PDGF- $\beta$ ( 85) and thyrotrophin releasing hormone (86).

One mechanism by which the changes in NPR-C transcript levels may occur has been suggested by the studies of Currie and colleagues (87-90). Using ligand-receptor binding methods, they have reported the preferential down-regulation of NPR-C in cultured endothelial cells exposed to high ANP concentrations and have reproduced the phenomenon by increasing intracellular cyclic GMP with 8-bromo-cyclic GMP and the cyclic GMP phosphodiesterase inhibitor, M\&B 22948 (87$89)$. In addition, in cultured vascular smooth muscle cells NPR-C was down-regulated by elevating cyclic GMP with sodium nitroprusside and by maneuvres that induce nitric oxide synthesis (90). Thus, down-regulation of NPR-C in hypertrophied cardiac tissue may be mediated by changes in intracellular cyclic GMP as a consequence of up-regulation of NPR-A and NPR-B which occurs contemporaneously. Furthermore, loss of NPR-C may occur not only in response to hypertrophic stimuli, but also in situations where nitric oxide levels are elevated in vivo, such as in septicemic shock and in patients receiving long-term nitrate therapy (91).

NPR-A and NPR-B are thought to mediate the functional effects of the natriuretic peptides by increasing intracellular cGMP concentration; the latter is associated with the majority of biological responses to the natriuretic peptides. It is not clear why the prevalence of NPR-A and NPR-B mRNA increases in cardiac hypertrophy, but we speculate that they may enhance the biological efficacy of the natriuretic peptides to prevent an excessive increase in cardiac mass. This may occur by a reduction in the workload of the heart, possibly by decreasing maximal cardiac contraction (44) and or by inducing early muscle relaxation (46). The receptors may also mediate a change in natriuretic peptide secretion. In the present study, the increase in NPR-A and NPR-B mRNA levels in some chambers was only transient, perhaps representing down-regulation of the receptors due to persistant ANP stimulation and/or altered intracardiac haemodynamics secondary to remodelling of the myocardium.

In summary, there is differential regulation of the cardiac NPR mRNAs with increasing cardiac mass in this AV fistula model. If these changes are mirrored at the receptor level, then they may represent an important mechanism by which the local effects of ANP and BNP on myocardium can be regulated independently from those in peripheral tissues. These findings also have important therapeutic implications. There is considerable interest in the pharmacological use of NPR-C specific ligands to reduce natriuretic peptide clearance, and thus enhance their actions. The pathophysiological loss of NPR-C, particularly if it is widespread, may reduce the rate of elimination of the natriuretic peptides, restricting the therapeutic potential of specific NPR-C ligands. In which case, reducing the degradation of the natriuretic peptides by inhibiting neutral endopeptidase 24.11 may be a more efficacious method of increasing the biological activity of these peptides.

\section{Acknowledgments}

This work was supported by the British Heart Foundation and a grant from Pfizer Central Research UK.

\section{References}

1. Brenner, B. M., B. J. Ballermann, M. E. Gunning, and M. L. Zeidel. 1990. Diverse biological actions of atrial natriuretic peptide. Physiol. Rev. 70:665-699.

2. Sudoh, T., K. Kangawa, N. Minamino, and H. Matsuo. 1988. A new natriuretic peptide in porcine brain. Nature (Lond.). 332:78-81.

3. Sudoh, T., N. Minamino, K. Kangawa, and H. Matsuo. 1990. C-type natriuretic peptide (CNP): a new member of natriuretic peptide family identified in porcine brain. Biochem. Biophys. Res. Commun. 168:863-870.

4. Seidman, C. E., A. D. Duby, R. M. Graham, J. A. Smith, and J. G. Seidman. 1984. The structure of rat preproatrial natriuretic factor as defined by a complementary DNA clone. Science (Wash. DC). 225:324-326.

5. Kojima, M., N. Minamino, K. Kangawa, and H. Matsuo. 1989. Cloning and sequence analysis of cDNA encoding a precursor for rat brain natriuretic peptide. Biochem. Biophys. Res. Commun. 159:1420-1426.

6. Kojima, M., N. Minamino, K. Kangawa, and H. Matsuo. 1990. Cloning and sequence analysis of a cDNA encoding a precursor for rat C-type natriuretic peptide (CNP). FEBS (Fed. Eur. Biochem. Soc.) Lett. 276:209-213.

7. Aburaya, M., N. Minamino, J. Hino, K. Kangawa, and H. Matsuo. 1989. Distribution and molecular forms of brain natriuretic peptide in the central nervous system, heart and peripheral tissue of rat. Biochem. Biophys. Res. Commun. 165:880-887.

8. Ueda, S., N. Minamino, M. Aburaya, K. Kangawa, S. Matsukura, and H. Matsuo. 1991. Distribution and characterization of immunoreactive porcine Ctype natriuretic peptide. Biochem. Biophys. Res. Commun. 175:759-767.

9. Suga, S-I., K. Nakao, H. Itoh, Y. Komatsu, Y. Ogawa, N. Hama, and H. Imura. 1992. Endothelial production of C-type natriuretic peptide and its marked augmentation by transforming growth factor- $\beta$. J. Clin. Invest. 90:1145-1149.

10. Stingo, A. J., A. L. Clavell, D. M. Heublein, C. M. Wei, M. R. Pittelkow, and J. C. Burnett. 1992. Presence of C-type natriuretic peptide in cultured human endothelial cells and plasma. Am. J. Physiol. 263:H1318-1321.

11. Heublein, D. M., A. L. Clavell, A. J. Stingo, A. Lerman, L. Wold, and J. C. Burnett. C-type natriuretic peptide immunoreactivity in human breast vascular endothelial cells. Peptides. 13:1017-1019.

12. Ruskoaho, H. 1993. Atrial natriuretic peptide: synthesis, release and metabolism. Pharmacol. Rev. 44:479-602.

13. Stingo, A. J., A. L. Clavell, L. L. Aarhus, and J. C. Burnett. 1992. Cardiovascular and renal effects of C-type natriuretic peptide. Am. J. Physiol. 262:H308-312.

14. Clavell, A. L., A. J. Stingo, C. M. Wei, D. M. Heublein, and J. C. Burnett. 1993. C-type natriuretic peptide: a selective cardiovascular peptide. Am. J. Physiol. 264:R290-295.

15. Anand-Srivastava, M., A. K. Srivastava, and M. Cantin. 1987. Pertussis toxin attenuates atrial natriuretic factor-mediated inhibition of adenylate cyclase: involvement of inhibitory guanine nucleotide regulatory protein. J. Biol. Chem. 262:4931-4934.

16. Anand-Srivastava, M., M. R. Sairam, and M. Cantin. 1990. Ring-deleted analogues of atrial natriuretic factor inhibit adenyl cyclase/cAMP system: possible coupling of clearance atrial natriuretic factor receptors to adenylate cyclase/ cAMP signal transduction system. J. Biol. Chem. 265:8566-8572.

17. Drewett, J. G., R. J. Ziegler, and G. J. Trachte. 1990. Neuromodulatory 
effects of atrial natriuretic factor are independent of guanylate cyclase in adrenergic neuronal phaechromocytoma cells. J. Pharmacol. Exp. Ther. 255:497-503.

18. MacFarland, R. T., B. D. Zelus, and J. A. Beavo. 1991. High concentrations of a cGMP-stimulated phosphodiesterase mediate ANP-induced decreases in cAMP and steroidogenesis in adrenal glomerulosa cells. J. Biol. Chem. 266:136-142.

19. Hu, R. M., E. R. Levin, A. Pedram, and H. J. Frank. 1992. Atrial natriuretic peptide inhibits the production and secretion of endothelin from cultured endothelial cells: mediation through the C receptor. J. Biol. Chem. 267:1738417389.

20. Isales, C. M., J. A. Lewicki, J. J. Nee, and P. Q. Barrett. 1992. ANP-(7-23) stimulates a DHP-sensitive $\mathrm{Ca}^{2+}$ conductance and reduces cellular cAMP via a cGMP-independent mechanism. Am. J. Physiol. 263:C334-342.

21. Hirata, M., C. H. Chang, and F. Murad. 1989. Stimulatory effects of atrial natriuretic factor on phosphoinositide turnover. Biochem. Biophys. Acta. 1010:346-351.

22. Barnett, R., P. A. Ortiz, S. Blaufox, S. Singer, E. P. Nord, and L. Ramasammy. 1990. Atrial natriuretic factor alters phospholipid metabolism in mesangial cells. Am. J. Physiol. 258:C37-45.

23. Berl, T., J. Mansour, and I. Teitlebaum. 1991. ANP stimulates phospholipase $\mathrm{C}$ in cultured RMICT cells: roles of protein kinases and $\mathrm{G}$ protein. $\mathrm{Am}$. $\mathrm{J}$. Physiol. 260:F590-F595.

24. Appel, R. G. 1992. Growth regulatory properties of atrial natriuretic factor. Am. J. Physiol. 262:F911-918.

25. Porter, J. G., R. Catalano, G. McEnroe, J. A. Lewicki, and A. A. Protter. 1992. C-type natriuretic peptide inhibits growth factor-dependent DNA synthesis in smooth muscle cells. Am. J. Physiol. 263:C1001-1006.

26. Chinkers, M., D. L. Garbers, M. Chang, D. G. Lowe, H. Chin, D. V. Goeddel, and S. Schulz. 1988. A membrane form of guanylate cyclase is an atrial natriuretic peptide receptor. Nature (Lond.). 338:78-83.

27. Lowe, D. G., M-S. Chang, R. Hellmiss, E. Chen, S. Singh, D. L. Garbers, and D. V. Goeddel. 1988. Human atrial natriuretic peptide receptor defines a new paradigm for second messenger signal transduction. EMBO (Eur. Mol. Biol. Organ.) J. 8:1377-1384.

28. Pandey, K. N., and S. Singh. 1990. Molecular cloning and expression of murine guanylate cyclase/atrial natriuretic factor peptide receptor cDNA. $J$. Biol. Chem. 265:12342-12348.

29. Chang, M., D. G. Lowe, M. Lewis, R. Hellmiss, E. Chen, and D. V. Goeddel. 1989. Differential activation by atrial and brain natriuretic peptides of two different receptor guanylate cyclases. Nature (Lond.). 341:68-71.

30. Schulz, S., S. Singh, R. A. Bellet, G. Singh, D. J. Tubb, H. Chin, and D. L. Garbers. 1989. The primary structure of a plasma membrane guanylate cyclase demonstrates diversity within this new receptor family. Cell. 58:1155-1162.

31. Fuller, F., J. G. Porter, A. E. Arfsten, J. Miller, J. W. Schilling, R. M. Scarborough, J. A. Lewicki, and D. B. Schenk. 1988. Atrial natriuretic peptide clearance receptor. J. Biol. Chem. 263:9395-9401.

32. Porter, J. G., A. E. Arfsten, F. Fuller, J. A. Miller, L. C. Gregory, and J. A Lewicki. 1990. Isolation and functional expression of the human atrial natriuretic peptide clearance receptor cDNA. Biochem. Biophys. Res. Commun. 171:796803.

33. Lowe, D. G., T. R. Camerato, and D. V. Goeddel. 1990. cDNA sequence of human atrial natriuretic peptide clearance receptor. Nucleic Acids Res 18:3412.

34. Koller, K. J., and D. V. Goeddel. 1992. Molecular biology of the natriuretic peptides and their receptors. Circulation. 86:1081-1088.

35. Koller, K. J., D. G. Lowe, G. L. Bennett, N. Minamino, K. Kangawa, H Matsuo, and D. V. Goeddel. 1991. Selective activation of B natriuretic peptide receptor by C-type natriuretic peptide. Science (Wash. DC). 252:120-123.

36. Bennett, B. D., G. L. Bennett, R. V. Vitangol, J. R. S. Jewett, J. Burnier, W. Henzel, and D. G. Lowe. 1991. Extracellular domain-IgG fusion proteins for three human natriuretic peptide receptors. J. Biol. Chem. 266:23060-23067.

37. Suga, S., K. Nakao, K. Hosoda, M. Mukoyama, Y. Ogawa, G. Shirakami, H. Arai, Y. Saito, Y. Kambayashi, K. Inouye, and H. Imura. 1992. Receptor selectivity of natriuretic peptide family, atrial natriuretic peptide, brain natriuretic peptide, and C-type natriuretic peptide. Endocrinology. 130:229-239.

38. Anand-Srivastava, M., M. Cantin, and J. Genest. 1985. Inhibition of pituitary adenylate cyclase by atrial natriuretic factor. Life Sci. 36:1873-1879.

39. Anand-Srivastava, M., and M. Cantin. 1986. Atrial natriuretic factor receptors are negatively coupled to adenylate cyclase in cultured atrial and ventricular cardiocytes. Biochem. Biophys. Res. Commun. 138:427-436.

40. Maack, T. 1992. Receptors of atrial natriuretic factor. Annu. Rev. Physiol. 54:11-27.

41. Okolicany, J., G. A. McEnroe, G. Y. Koh, J. A. Lewicki, and T. Maack. 1992. Clearance receptor and neutral endopeptidease-mediated metabolism of atrial natriuretic factor. Am. J. Physiol. 263:F546-553.

42. Barclay, P. L., J. A. Bennett, P. M. Greengrass, A. Griffin, G. M. R. Samuels, and N. B. Shepperson. 1992. The pharmacokinetics of ${ }^{125}$ I-atrial natriuretic factor in anaesthetised rats: effects of neutral endopeptidase inhibition with candoxitrilat and of ANF-C receptor blockade. Biochem. Pharmacol. 44:10131022.
43. Cramb, G., R. Banks, E. L. Rugg, and J. F. Aiton. 1987. Actions of atrial natriuretic peptide (ANP) on cyclic nucleotide concentrations and phosphatidylinositol turnover in ventricular myocytes. Biochem. Biophys. Res. Commun. 148:962-970.

44. Neyses, L., and H. Vetter. 1989. Action of atrial natriuretic peptide and angiotensin II on the myocardium: studies in isolated rat ventricular myocytes. Biochem. Biophys. Res. Commun. 163:1435-1443.

45. Tei, M., M. Horie, T. Makita, H. Suzuki, A. Hazama, Y. Okada, and C. Kawai. 1990. Atrial natriuretic peptide reduces the basal level of cytosolic free calcium in guinea-pig cardiac myocytes. Biochem. Biophys. Res. Commun. 167:413-418.

46. Meulemans, A. L., K. R. Sipido, S. U. Sys, and D. L. Brutsaert. 1988. Atriopeptin III induces early relaxation of isolated mammalian papillary muscle. Circ. Res. 62:1171-1174.

47. Rutherford, R. A. D., J. Wharton, L. Gordon, G. Moscoso, M. H. Yacoub, and J. M. Polak. 1992. Endocardial localisation and characterisation of natriuretic peptide binding sites in human fetal and adult heart. Eur. J. Pharmacol. 212:1-7.

48. Oehlenschlager, W. F., H. Baron, H. Schomer, and M. G. Currie. 1989. Atrial and brain natriuretic peptides share binding sites in the kidney and heart. Eur. J. Pharmacol. 161:159-164.

49. Mantyh, C. R., L. Kruger, N. C. Brecha, and P. W. Mantyh. 1986. Localization of specific binding sites for atrial natriuretic factor in peripheral tissues of guinea pig, rat and human. Hypertension. 8:712-721.

50. Wilcox, J. H., A. Augustine, D. V. Goeddel, and D. G. Lowe. 1991. Differential regional expression of three natriuretic peptide receptor genes within primate tissues. Mol. Cell. Biol. 11:3454-3462.

51. Nunez, D. J. R., M. C. Dickson, and M. J. Brown. 1992. Natriuretic peptide receptor mRNAs in the rat and human heart. J. Clin. Invest. 90:19661971.

52. Wilkins, M. R., S. L. Settle, P. T. Stockmann, and P. Needleman. 1990 Maximizing the natriuretic effect of endogenous atriopeptin in a rat model of heart failure. Proc. Natl. Acad. Sci. USA. 87:6465-6469.

53. Qing, G., and R. Garcia. 1993. Characterisation of plasma and tissue atrial natriuretic factor during development of moderate high output heart failure in the rat. Cardiovasc. Res. 27:464-470.

54. Fort, P., L. Marty, M. Piechaczyk, S. E. Sabrouty, C. Dani, P. Jeanteur, and J. M. Blanchard. 1985. Various rat adult tissues express only one majo mRNA species from the glyceraldehyde-3-phosphate-dehydrogenase multigenic family. Nucleic Acids Res. 13:1431-1442.

55. Chelly, J., J.-C. Kaplan, P. Maire, S. Gautron, and A. Kahn. 1988. Transcription of the dystrophin gene in human muscle and non-muscle tissues. Nature (Lond.). 333:858-860.

56. Nunez, D. J. R., A. P. Davenport, and M. J. Brown. 1990. Atrial natriuretic factor mRNA and binding sites in the adrenal gland. Biochem. J. 271:555558.

57. Nunez, D. J., A. P. Davenport, P. C. Emson, and M. J. Brown. 1989. A quantitative "in-situ" hybridization method using computer-assisted image analysis: validation and measurement of atrial-natriuretic-factor mRNA in the rat heart. Biochem. J. 263:121-127.

58. Sarker, G., and S. Sommer. 1989. Access to a messenger RNA sequence or its protein product is not limited by tissue or species. Science (Wash. DC). 244:331-334.

59. Chelly, J., J.-P. Concordet, J.-C. Kaplan, and A. Kahn. 1989. Illegitimate transcription: transcription of any gene in any cell type. Proc. Natl. Acad. Sci. USA. 86:2617-2621.

60. Dagnino, L., J. Lavigne, and M. Nemer. 1992. Increased transcripts for B-type natriuretic peptide in spontaneously hypertensive rats: quantitative polymerase chain reaction for atrial and brain natriuretic peptide transcripts. Hypertension. 20:690-700.

61. Drexler, H., J. Hanze, M. Finckh, W. Lu, H. Just, and R. E. Lang. 1989. Atrial natriuretic peptide in a rat model of cardiac failure. Circulation. 79:620633.

62. Lattion, A., J. Michel, E. Arnauld, P. Corvol, and F. Soubrier. 1986. Myocardial recruitment during ANF mRNA increase with volume overload in the rat. Am. J. Physiol. 251:H890-H896.

63. Lee, R. T., K. D. Bloch, J. M. Pfeffer, M. A. Pfeffer, E. J. Neer, and C. E. Seldman. 1988. Atrial natriuretic factor gene expression in ventricles of rats with spontaneous biventricular hypertrophy. J. Clin. Invest. 81:431-434.

64. Day, M. L., D. Schwartz, R. C. Wiegand, P. T. Stockman, S. R. Brunnert, H. E. Tolunay, M. G. Currie, D. G. Standaert, and P. Needleman. 1987. Ventricular atriopeptin: unmasking of messenger RNA and peptide synthesis by hypertrophy or dexamethasone. Hypertension. 9:485-491.

65. Stockmann, P. T., D. H. Will, R. C. Wiegand, and P. Needleman. 1988. Ventricular atriopeptin synthesis in chronic cardiac overload. In Biological and Molecular Aspects of Atrial Factors. P. Needleman, editor. Alan R. Liss Inc., New York. 233-240.

66. Haass, M., T. A. Fischer, J. Hanze, W. Saggau, R. E. Lang, and R. Dietz. 1990. Atrial natriuretic peptide mRNA in patients with heart disease. $A m$. $J$. Hypertens. 3:234-236. 
67. Fischer, T. A., M. Haass, R. Dietz, R. C. Willenbrock, W. Saggau, R. E. Lang, and W. Kubler. 1991. Transcription, storage and release of atrial natriuretic factor in the failing human heart. Clin. Sci. 80:285-291.

68. Parker, T. G., and M. D. Schneider. 1991. Growth factors, proto-oncogenes, and plasticity of the cardiac phenotype. Annu. Rev. Physiol. 53:179-200.

69. Takahashi, T., P. D. Allen, and S. Izumo. 1992. Expression of A-, B-, and C-type natriuretic peptide genes in failing and developing human ventricles: correlation with expression of the Ca-ATPase gene. Circ. Res. 71:9-17.

70. Bloch, K. D., J. A. Scott, J. B. Zisfein, J. T. Fallon, M. N. Margolies, C. E. Seidman, G. R. Matsueda, C. J. Homcy, R. M. Graham, and J. B. Seidman. 1986 Biosynthesis and secretion of proatrial natriuretic factor by cultured rat cardiocytes. Science (Wash. DC). 230:1168-1171.

71. Wei, Y., C. P. Rodi, M. L. Day, R. C. Weigand, L. D. Needleman, B. R. Cole, and P. Needleman. 1987. Developmental changes in the rat atriopeptin hormonal system. J. Clin. Invest. 79:1325-1329.

72. Huang, M., R. L. Hester, and A. C. Guyton. 1992. Hemodynamic changes in rats after opening an arteriovenous fistula. Am. J. Physiol. 262:H846-851.

73. Ruzicka, M., B. Yuan, E. Harmsen, and F. H. Leenen. 1993. The reninangiotensin system and volume overload-induced cardiac hypertrophy in rats: effects of angiotensin converting enzyme inhibitor versus angiotensin II receptor blocker. Circulation. 87:921-930.

74. Michel, J. B., J. L. Salzmann, N-M. Ossondo, P. Brueval, and J. P. Camilleri. 1986. Morphometric analysis of collagen network and plasma perfused capillary bed in the myocardium of rats during evolution of cardiac hypertrophy. Basic Res. Cardiol. 81:142-154.

75. Gerdes, A. M., S. E. Campbell, and D. R. Hilbelink. 1988. Structura remodeling of myocytes in rats with arteriovenous fistulas. Lab. Invest. 59:857861 .

76. Takeda, N., I. Nakamura, T. Okubo, and M. Nagano. 1990. Altered myocardial contractility and energetics in hypertrophied myocardium. Jpn. Circ. J. 54:540-546.

77. Schiffrin, E. L. 1988. Decreased density of binding sites for atrial natriuretic peptide on platelets of patients with severe congestive heart failure. Clin. Sci. 74:213-218.

78. Tsutamoto, T., T. Kanamori, A. Wada, and M. Kinoshita. 1992. Uncoupling of atrial natriuretic peptide extraction and cyclic guanosine monophosphate production in the pulmonary circulation in patients with severe heart failure. $J$ Am. Coll. Cardiol. 20:541-546.
79. Tsunoda, K, F. A. O. Mendelsohn, P. M. Sexton, S. Y. Chai, G. P Hodsman, and C. I. Johnston. 1988. Decreased atrial natriuretic peptide binding in renal medulla in rats with chronic heart failure. Circ. Res. 62:155-161.

80. Nunez, D. J., S. Vassilikioti, and M. J. Brown. 1992. The human atrial natriuretic factor (ANF) ' $C$ ' receptor is encoded by two messenger RNAs. $J$. Physiol. (Lond.). 446:307P. (Abstr.)

81. Mizuno, T., M. Iwashina, M. Itakura, H. Hagiwara, and S. Hirose. 1993. A variant of the type $C$ atrial natriuretic peptide receptor generated by alternative RNA splicing. J. Biol. Chem. 268:5162-5167.

82. Ohyama, Y., K. Miyamoto, Y. Saito, N. Minamino, K. Kangawa, and H. Matsuo. 1992. Cloning and characterization of two forms of C-type natriuretic peptide receptor in rat brain. Biochem. Biophys. Res. Commun. 183:743-749.

83. Bianchi, C., J. Gutkowska, G. Thibault, R. Garcia, J. Genest, and M. Cantin. 1985. Radioautographic localization of ${ }^{125}$ I-atrial natriuretic factor (ANF) in rat tissues. Histochemistry. 82:441-452.

84. Katafuchi, T., T. Mizuno, H. Hagiwara, M. Itakura, T. Ito, and S. Hirose. 1992. Modulation by $\mathrm{NaCl}$ of atrial natriuretic peptide receptor levels and cyclic GMP responsiveness to atrial natriuretic peptide of cultured vascular endothelial cells. J. Biol. Chem. 267:7624-7629.

85. Bowen-Pope, D. F., and R. Ross. 1985. Methods for studying the plateletderived growth factor receptor. Methods Enzymol. 109:69-100.

86. Oron, Y., R. E. Straub, P. Traktman, and M. C. Gershengorn. 1987. Decreased TRH receptor mRNA activity precedes homologous downregulation: assay in oocytes. Science (Wash. DC). 238:1406-1408.

87. Kato, J., K. L. Lanier-Smith, and M. G. Currie. 1991. Cyclic GMP downregulates atrial natriuretic peptide receptors on cultured vascular endothelia cells. J. Biol. Chem. 266:14681-14685.

88. Kato, J., and M. G. Currie. 1992. Suppression of atrial natriuretic peptide (ANP) receptor recovery from homologous down-regulation by 8-bromo-cGMP in endothelial cells. Eur. J. Pharmacol. 225:113-117.

89. Kato, J., W. F. Oehlenschlager, W. H. Newman, and M. G. Currie. 1992. Inhibition of endothelial cell clearance of atrial natriuretic peptide by cyclic GMP treatment. Biochem. Biophys. Res. Commun. 182:420-424.

90. Kato, J., T. P. Misko, and M. G. Currie. 1992. Induction of nitric oxide synthase regulates atrial natriuretic peptide receptors in vascular smooth muscle cells. Eur. J. Pharmacol. 244:153-159.

91. Moncada, S., R. M. J. Palmer, and E. A. Higgs. 1991. Nitric oxide: physiology, pathophysiology and pharmacology. Pharmacol. Rev. 43:109-142. 